\title{
MOTIVASI MENABUNG NASABAH MELALUI SISTEM SERVICE JEMPUT BOLA DI BMT NU
}

\author{
Muslihul Umam \& Rifki Rufaida \\ IAI Nazhatut Thullab Sampang \\ Email: muslehumam@gmail.com
}

\begin{abstract}
Abstrak
Agama Islam menganjurkan untuk Menabung, karena dengan menabung berarti seseorang mempersiapkan diri untuk pelaksanaan dan perencanaan masa yang akan datang sekaligus untuk menghadapi hal-hal yang tidak diinginkan. Penelitian ini menggunakan pendekatan kualitatif deskriptif karena pendekatan ini cocok digunakan untuk memperoleh pemahaman mendalam tentang fenomena sosial. Metode yang digunakan dalam pemgumpulan data adalah observasi, wawancara dan dokumentasi. Hasil penilitiannya Motivasi nasabah menabung di BMT NU Camplong yaitu, (1) kemudahan mendaftar menjadi nasabah yang tidak harus datang langsung ke lokasi/kantor dan menunggu antrian berjam-jam, (2) kemudahan menabung tidak harus mendatangi kantor BMT NU Camplong, (3) kemudahan pengambilan/penarikan, nasabah hanya memberi tahu petugas BMT NU yang mempunyai tugas keliling setiap hari atau menghubungi melalui telpon pada saat jam kerja, maka petugas akan mengantar sesuai dengan jumlah yang akan ditarik. Berikut keuntungan yang didapatkan nasabah, yaitu (1) setoran awal hanya dengan Rp.10.000, (2) memperoleh keuntungan Bagi Hasil 40\%, (3) nasabah banyak mengerti ilmu tentang implementasi keuangan syariah.
\end{abstract}

Kata Kunci: Motivasi Menabung, Sistem Service Jemput Bola

\begin{abstract}
Absract:
Islam recommends for saving, because saving means someone prepares for future implementation and planning as well as dealing with unwanted things. This study used a descriptive qualitative approach because this approach is suitable to be used to obtain an in-depth understanding of social phenomena. The method used in collecting data were observation, interviews and documentation. The results of this research Motivation of customers saving at BMT NU Camplong are; (1) an easy registration to become customers who did not have to come directly to the location or office and waiting for queues for hours, (2) the ease of saving does not have to go to the BMT NU Camplong office, (3) the ease of withdrawal, customers only notify the NU BMT officer who has a duty every day or contact by telephone during working hours, the officer will deliver according to the amount to be withdrawn. The following are the benefits obtained by the customer, they are; (1) the initial deposit is only Rp. 10,000, (2) get 40\% profit sharing, (3) the customers understand a lot about the knowledge of the implementation of sharia finance.
\end{abstract}

Keywords: Motivation of Saving, Ball Pick Up Service System 


\section{Pendahuluan}

Dalam UU No. 21 Tahun 2010 dengan ditetapakannya UUD ini dapat membawa dampak positif dunia perbankan kita. Terutama bagi dunia perbankan syariah di tanah air, berdirinya bank-bank baru yang bekerja berdasarkan prinsip syariah akan menambah semarak lembaga keuangan syariah yang telah ada seperti: Bank Umum Syariah, Bank Pembiayaan Rakyat Syariah (BPRS) dan Baitul Mal wa Tamwil (BMT). ${ }^{1}$

BMT adalah balai usaha mandiri terpadu yang isinya berintikan bayt al-mal wa at-tamwil dengan kegiatan mengembangkan usaha-usaha produktif dan investasi dalam meningkatkan kualitas kegiatan ekonomi pengusaha kecil bawah dan kecil dengan mendorong kegiatan menabung dan menunjang pembiayaan kegiatan ekonominya. $^{2}$

Dengan pesatnya perkembangan BMT ketika itu, BMT menjadi lembaga keuangan mikro syariah yang mempunyai peranan yang penting di tengah-tengah masyarakat khususnya bagi masyarakat yang mempunyai pendapatan rendah. Dan pendirian BMT juga berdampak positif bagi ekonomi kerakyatan.

Dengan banyaknya lembaga keungan baik Syariah dan Konvensional patut kita syukuri karena dengan meningkatknya lembaga keuangan berarti sudah semakin meningkat pula rakyat yang akan menjadi nasabah dan otomatis sudah semakin sadar akan pentingnya menabung.

Menabung bukan masalah yang sulit bagi masyarakat karena menabung merupakan tindakan yang dianjurkan oleh agama Islam, karena dengan menabung berarti seseorang mempersiapkan diri untuk pelaksanaan perencanaan masa yang akan datang sekaligus untuk menghadapi hal-hal yang tidak diinginkan. Proses dalam menabung harus ditunjang oleh aturan yang tidak terlalu mengikat dan sistem yang mudah agar nasabah mudah untuk tertarik dalam menabung.

BMT NU merupakan BMT yang aturan menabungnya memanjakan calon ataupun anggota nasabah, banyak produk yang ditawarkan untuk memanjakan nasabah termasuk salah satunya adalah Tabungan (TABAH) Mudhorobah tabungan yang bisa mempermudah anda dalam memenuhi kebutuhan sehari-hari karena setoran dan penarikan dapat dilakukan kapan saja dan memperoleh keuntungan Bagi Hasil 40\%. Dan menggunakan akad Mudharobah Mutlaqoh. Setoran awal Rp.10.000 selanjutnya minimal Rp.2500.3 Bukan itu saja Tabungan (TABAH) Mudhorobah tabungan yang melayani pelayanan jemput bola untuk menjangkau ke pelosok desa sehingga para petani dan pedagang bisa juga ikut terbantu dengan adanya BMT NU cabang Camplong Sampang.

\section{Metode Penelitian}

Metode penelitian ini menggunakan penelitian Kualitatif, pendekatan kualitatif merupakan proses penelitian yang bertujuan untuk memahami dan

\footnotetext{
${ }^{1}$ Muhamad, Manajemen Dana Bank Syariah (Jakarta: Rajawali Pers, 2014), 2. ${ }^{2}$ Ahmad Hasan Ridwan, Manajemen Baitul Mal Wa at-tamwil, (Bandung: CV Pustaka Setia, 2013), 23. ${ }^{3} \mathrm{Http} / / /$ bmtnujatim.com(Diakses pada 24 April 2019, pukul 16:45).
} 
mengeksplorasi fenomena atau pada obyek yang diteliti, sehingga memperoleh pemahaman yang medalam dan menemukan sesuatu yang unik. ${ }^{4}$

Dalam penelitian kualitatif, yang menjadi instrumen atau alat penelitian adalah peneliti itu sendiri. Oleh karena itu peneliti sebagai instrumen juga harus "divalidasi" seberapa jauh peneliti kualitatif siap melakukan peneliti yang selanjutnya pergi ke lapangan. Peneliti kualitatif sebagai human Instrumen, berfungsi menetapkan fokus penelitian, memilih informan sebagai sumber data, melakukan pengumpulan data, menilai kualitas data, analisis data, menafsirkan data dan membuat kesimpulan atas temuannya. ${ }^{5}$ Lokasi dalam penelitian ini adalah para nasabah yang menabung atau pernah menabung di BMT NU Cabang Camplong.

Dalam pengumpulan data peneliti melakukan pengumpulan data dengan melakukan observasi (pengamatan) interview (wawancara), dokumentasi dan gabungan keempatnya. ${ }^{6}$

Dalam analisis data kualitatif, Bogdan menyatakan Bahwa "Data analysis is the proces of systeatically searching and arranging the interview transcripts, field notes, and other materials that you accumulate to increas your own understanding of them and to enable you to presen what you have discovered to other" Analisis data diperoleh dari hasil wawancara, catatan lapangan, dan bahan-bahan lain, sehingga dapat mudah difahami, dan temuannya dapat diinformasikan kepada orang lain. Analisis data dapat dilakukan dengan mengorganisasikan data, menjabarkannya, dan melakukannya dengan sintesa, menyusun kedalam pola, memilih mana yang penting dan yang akan dipelajari, dan membuat kesimpulan yang dapat diceritakan kepada orang lain. ${ }^{7}$

\section{Strategi Pemasaran}

Inti dari pemasaran adalah mengidentifikasi dan memenuhi kebutuhan manusia dan sosial, serta memenuhi kebutuhan dengan cara yang menguntungkan, serta menumbuhkan pelanggan dengan menciptakan, menghantarkan, dan mengkomunikasikan nilai pelanggan yang unggul. Konsep inti dalam pemasaran adalah Kebutuhan, Keinginan, dan permintaan. Kebutuhan adalah Syarat hidup dasar Manusia, sedangkan keinginan ketika diarahkan ke obyek tertentu yang dapat memuaskan kebutuhan tersebut, sedangkan permintaan adalah keinginan akan produk-produk tertentu yang didukung kemampuan unuk membayar. ${ }^{8}$

\section{Motivasi}

Ada beberapa defini Motivasi, yaitu: "motivasi menunjuk kepada semua gejala yang terkandung dalam stimulasi kearah tujuan tertentu, diman sebelumnya tidak ada gerakan kearah tujuan tersebut". Sementara itu Omar Hamalik mengutip apa yang disebutkan oleh Mc Doanald yang menyebutkan: "motivation is an energy change within the person characterized by effective arausal and anticipatory goal reaction," (Motivasi adalah suatu perubahan sumber energi dalam pribadi

\footnotetext{
4 Sugiyono, Metode Penelitian Kualitatif, (Bandung: Alfabeta, 2017), 23.

5Ibid, 101-102.

${ }^{6} \mathrm{Ibid}, 104$.

7Ibid, 130.

8Philip Kotler danKevin Lane Keller, Manajemen Pemasaran, edisi 13 (Jakarta: Erlangga, 2009), 8-9
} 
seseorang yang ditandai dengan timbulnya afektif dan reaksi untuk mencapai tujuan). ${ }^{9}$

Motivasi sangat erat hubugannya dengan kebutuhan, sebab memang motivasi muncul karena kebutuhan. Seseorang akan terdorong untuk bertindak manakala dalam dirinya ada kebutuhan. Kebutuhn ini yang menimbulkan keadaan ketidak seimbangan (ketidak puasan), yaitu ketegangan-ketegangan, dan ketegangan itu akan hilang manakala kebutuhan itu terpenuhi. ${ }^{10}$

Ditinjau dari intensitasnya, Motivasi terdiri dari motivasi primer dan motivasi sosial atau sekunder, Motivasi Primer adalah motivasi yang didasarkan pada motiv-motiv dasar, yang umumnya berasal dari segi biologis dan jasmani sehingga perilakunya terpengaruh oleh insting. Sedangkan insting mempnyai empat ciri, yitu tekanan, sasaran, objek, dan sumber. Tekanan adalah kekuatan yang memotivasi individu untuk bertingkah laku. Semakin besar energi dalam insting , maka tekanan terhadap individu semakin besar. Sasaran adalah kepuasan dan kesenangan. Objek insting adalah hal-hal yang memuaskan insting. Adapun sumber insting adalah keadann jasmaniyah dan individu. Motivasi Skunder atau sosial sangat penting dan memegang peranan penting dan besar dalam kehidupan manusia. Motivasi sekunder sebagaimana yang dinyatakan Mc Cean terdiri dari: (a) berprestasi dalam bekerja berkualitas produksi tinggi, (b) memperoleh kasih sayang, (c) memperoleh kekuasaan. ${ }^{11}$

Motif adalah daya dalam diri seseorang yang mendorongnya untuk melakukan sesuatu, atau keadaan seseorang atau organisme yang menyebabkan kesiapannya untuk memulai serangkaian tingkahlaku atau pembuatan. Sedangkan motivasi adalah suatu proses untuk menggiatkan motif-motif menjadi perbuatan atau tingkah laku untuk memenuhi kebutuhan dan mencapai tujuan, atau keadaan dan kesiapan dalam diri individu yang mendorong tingkah lakunya untuk berbuat sesuatu dalam mencapai tujuan tertentu. Motivasi dapat timbul dari dalam diri individu (motivasi intrinsik), dan dapat pula timbul akibat pengaruh dari luar individu (motivasi ekstrinsik). ${ }^{12}$

Teori motivasi yang dikembangkan oleh Abraham H. Maslow pada intinya berkisar pada pendapat bahwa manusia mempunyai lima tingkat atau hierarki kebutuhan, yaitu : (1) kebutuhan fisiologikal (physiological needs), seperti : rasa lapar, haus, istirahat dan sex; (2) kebutuhan rasa aman (safety needs), tidak dalam arti fisik semata, akan tetapi juga mental, psikologikal dan intelektual; (3) kebutuhan akan kasih sayang (love needs); (4) kebutuhan akan harga diri (esteem needs), yang pada umumnya tercermin dalam berbagai simbol-simbol status; dan (5) aktualisasi diri (self actualization), dalam arti tersedianya kesempatan bagi seseorang untuk mengembangkan potensi yang terdapat dalam dirinya sehingga berubah menjadi kemampuan nyata. ${ }^{13}$

\footnotetext{
${ }^{9}$ H.M. MochlisSholchin, Psikologi Belajar, (Surabaya: Pena Salsabila, 2013), 167.

${ }^{10}$ Wina Sanjaya, Strategi Pembelajaran Berorentasi Standar Proses Pendidikan, (Jakarta:Kencana, 2011), 28

${ }^{11}$ H.M. Mochlis Sholchin, Psikologi Belajar, 72.

${ }^{12}$ Moh. Uzer Usman, Menjadi Guru Profesional, (Bandung: PT Remaja Rosdakarya, 2004), 28-29.

${ }^{13}$ https://s3.amazonaws.com/academia.edu.documents/36863728/Teori-teorimotivasid.

(Diaksespada 24 April 2019, pukul 16:00).
} 


\section{Menabung Nasabah}

Menurut kamus besar bahasa Indonesia, menabung merupakan kata kerja yang memiliki arti yaitu menyimpan uang (dicelengan, pos, bank, dsb). Secara arti yang luas menabung dapat diartikan sebagai suatu kegiatan menyisihkan sebagian penghasilannya untuk dikumpulkan sebagai cadangan dihari depan atau dihari yang akan datang. Dalam Undang-Undang Perbankan nomor 10 tahun 1998 tabungan merupakan simpanan yang penarikannya hanya dapat dilakukan menurut syarat-syarat tertentu yang disepakati, tetapi tidak dapat ditarik dengan cek, bilyet giro dan atau alat lainnya yang dipersamakan dengan itu. Syarat-syarat penarikan tertentu maksudnya adalah sesuai dengan perjanjian atau kesepakatan yang telah dibuat antara bank dengan si penabung. Misalnya dalam frekuensi penarikan, apakah 2 kali seminggu atau setiap hari atau mungkin setiap saat. Yang jelas haruslah sesuai dengan perjanjian sebelumnya antara bank dengan nasabah. Kemudian dalam hal sarana atau alat penarikan juga tergantung dengan perjanjian antara keduanya. ${ }^{14}$

Nasabah adalah perbandingan, pertalian, orang yang biasa berhubungan dengan baik atau menjadi pelanggan bank (dalam hal keuangan). Nasabah (bank customer) adalah sebutan untuk orang atau badan usaha yang mempunyai rekening simpanan atau pinjaman pada sebuah bank tertentu. Atau nasabah bank (bank customer) adalah pihak yang menggunakan jasa bank. ${ }^{15}$

\section{Sistem (Service) Jemput Bola}

Layanan(Service) jemput bola ialah layanan tambahan bagi nasabah tabungan, maupun deposito, dimana nasabah dipermudah untuk pembukaan tabungan/deposito maupun penyetoran tabungan/deposito dengan didatangi oleh marketing, sehingga nasabah tidak repot untuk datang ke BMT NU Camplong. ${ }^{16}$ Dari perspektif syariah, jemput bola dapat dipahami sebagai upaya BMT untuk mengembangkan tradisi silaturahmi yang meurut Rasulullah SAW dapat menambah rezeki, memanjangkan umur, serta menjauhkan manusia dari dendam dan kebencian. Selain itu jemput bola juga merupakan strategi yang dilakukan BMT dengan cara petugas langsung mendatangi nasabah atau calon nasabah dan petugas leluasa menjelaskan mengenai konsep keuangan syariah serta sistem dan prosedur operasional BMT. ${ }^{17}$.

\footnotetext{
14Ervina Lilis Saadah (Sistem Layanan Jemput Bola Dalam Meningkatkan Motivasi Menabung Nasabah Pada BMT Muda) (Skripsi, UIN SunanAmpel Surabaya, 2016), 15.

15http://eprints.walisongo.ac.id/892/3/082411082_bab2.pdf. (Diakses pada 24 April 2019, pukul 18:00).

16Hendri Triandini, "pengaruh Layanan Jemput Bola Produk Funding Terhadap DPK dan Jumlah Nasabah" Jurnal Etikonomi Universitas Prof Muhammadiyah Dr. Hamka, Vol. 12 No. 2, Oktober 2013, 134.

17Ervina Lilis Saadah, Sistem Layanan Jemput Bola Dalam Meningkatkan Motivasi Menabung Nasabah Pada BMT Muda, 14-15.
} 


\section{Hasil dan Pembahasan \\ Motivasi Menabung Nasabah}

Sebelum berdirinya BMT NU Camplong masyarakat Camplong daerah pesisir pantai dan Masyarakat pedesaannya khususnya belum mengenal apa itu lembaga Keuangan BMT baik BMT NU atau Lembaga Keuangan lainnya, namun tidak adanya organisasi lembaga keuangan formal, masyarakat Camplong bukan tidak ada Motivasi menabung, bahkan sebelum ada lembaga keuangan BMT NU rakyat sudah banyak yang termotivasi untuk menabung, Salah satu nasabah yang sudah termotivasi menabung dan sudah menabung sejak sebelum munculnya BMT NU Camplong adalah Bpk H. Rofiqi, beliau adalah seorang pedagang yang awalnya menabung di lembaga pendidikan Atsarus Salafiyah di Desa Sejati Camplong Sampang, setiap hari beliau menabung melalui dititipkan anaknya yang masih SDI dan kebetulan lembaga tersebut menyediakan sarana tabungan untuk orang tua yang ingin menabung, proses menabungnya ditipkan melalui anak yang sekolah di lembaga tersebut. ${ }^{18}$ Hal serupa terjadi terhadap bapak Ust. Zayadi yang berprofesi sebagai guru Honorer beliau pertama menabung di lembaga pendidikan Nuruss Salafiyah di Desa Sejati Camplong Sampang, karena di lembaga tersebut anaknya menempuh pendidikan yang juga menyediakan jasa tabungan, namun kelemahan dari menabung di sekolah tersebut adalah, pertama Kurangnya rasa aman pabila menabung dalam jumlah banyak karena yang membawa hanya anak sekolah yang masih menempuh Seolah ditingkat dasar, kedua tidak bisa diambil sewaktu-waktu untuk kebutuhan yang mendadak karena aturan dalam menabung di lembaga pendidikan tersebut hanya boleh diambil apabila sudah mencapai akhir tahun atau kenaikan kelas. ${ }^{19}$

\section{Sistem Service Jemput Bola}

BMT NU merupakan BMT yang sistem menabungnya memanjakan calon ataupun anggota nasabah, banyak produk yang ditawarkan untuk memanjakan nasabah termasuk salah satunya adalah Tabungan (TABAH) Mudhorobah tabungan yang bisa mempermudah anda dalam memenuhi kebutuhan sehari-hari karena setoran dan penarikan dapat dilakukan kapan saja dan memperoleh keuntungan bagi hasil 40\%. Dan menggunakan akad Mudharobah Mutlaqoh. Setoran awal Rp. 10.000 selanjutnya minimal Rp. 2500 dan menyetorkan Identitas sudah langsug mendapatkan kartu tabungan dan sudah menjadi nasabah tanpa harus mendatangi lokasi atau kantor. Bukan itu saja Tabungan (TABAH) Mudhorobah tabungan yang melayani pelayanan jemput bola untuk menjangkau ke pelosok desa sehingga para petani dan pedagang bisa juga ikut terbantu dengan adanya BMT NU cabang Camplong Sampang. Tabungan (TABAH) Mudhorobah merupakan sistem tabungan yang didatangi oleh petugas BMT NU dan nasabah tinggal menunggu di rumah, setoran selalu diambil oleh petugas BMT NU setiap harinya dan tidak ada biaya pemotongan sedikitpun sehingga nasabah terbantu untuk menabung dalam jumlah sedikit ataupun dalam jumlah banyak (tidak ada batasan maksimal atau minimal) dan bisa diambil sewaktu- waktu apabila dibutuhkan dan pengambilan akan diantar

18Wawancara dengan Bpk H. Rofiqi, tanggal 20 April 2019 di rumah Sejati Camplong Sampang. ${ }^{19}$ Wawancara dengan Ust. Zayadi, tanggal 20 April 2019 di rumah Gruggak Camplong Sampang. 
oleh petugas BMT NU tanpa uang administrasi atau potongan, sistem Tabungan (TABAH) Mudhorobah termasuk sistem tabungan yang aman karena nasabah akan mendapatkan buku tabungan untuk mengontrol semua tranksaksi baik menabung ataupun menarik tabungan, sehingga nasabah bisa memantau segala jenis transaksinya dan meminimalkan resiko kekeliruan dan kehilangan uang nasabah, sehingga nasabah sangat terbantu dan termotivasi untuk menabung.

\section{Motivasi Menabung Nasabah}

Alasan utama nasabah menabung di BMT NU adalah Sistem layanan jemput bola yang dilakukan oleh BMT NU, nasabah banyak diberikan kemudahan dan keuntungan oleh BMT NU melalui Tabungan (TABAH) Mudhorobah diantara kemudahan dan keuntungannya, Kemudahan yaitu (1) kemudahan mendaftar menjadi nasabah yang tidak harus datang ke lokasi/kantor menunggu antrian berjam-jam, calon nasabah hanya berpesan ke tetangga yang sudah menjadi nasabah untuk memberikan informasi bahwa calon nasabah akan mendafatar atau menghubungi nomer telpon petugas dari kantor BMT NU. (2) kemudahan menabung tidak harus mendatangi kantor atau lokasi, jumlah berapapun akan diambil yang setiap hari petugas dari BMT NU datang kerumah-rumah yang sudah menjadi nasabah sehingga menghemat uang transportasi. (3) kemudahan pengambilan/penarikan, nasabah hanya memberi tahu petugas dari BMT NU yang keliling setiap hari atau menghubungi telpon pada saat jam kerja maka petugas akan mengantar sesuai dengan jumlah yang akan ditarik. Berikut keuntungan yang didapatkan nasabah, yaitu (1) setoran awal hanaya dengan Rp.10.000 selanjutnya minimal Rp. 2500 nasabah sudah mempunyai tabungan dengan tanda buku tabungan yang akan memantau transaksi yang akan dilakukan baik menabung atau menarik uang tabungan, (2) memperoleh keuntungan Bagi Hasil 40\%, (3) nasabah banyak mengerti ilmu tentang implementasi keuangan syariah dari peraktek yag dilakukan oleh BMT NU.

Bermacam dorongan dan motivasi menabung nasabah di BMT NU semua tidak lepas dari kebutuhan dan tujuan yang jelas. Yang menurut Abraham H. Maslow bahwa manusia mempunyai lima tingkat atau hierarki kebutuhan, yaitu :

1. Kebutuhan fisiologikal (physiological needs),

Nasabah menabung di BMT NU untuk kebutuhan primer dimasa yang akan datang sehingga apabila dibutuhkan dihari-hari berikutnya bisa dengan mudah untuk mengambil untuk memenuhi kebutuhan primernya, terutama masyarakat desa yang sangat peduli akan kebutuhan primernya sehingga menabung bukan hanya dalam bentuk uang akan tetapi juga dalam bentuk hasil panen, seperti jagung, padi, kedelai, semata-mata ingin memenuhi kebutuhan hidupnya dimasa yang akan datang.

2. Kebutuhan rasa aman (safety needs)

Alasan Nasabah menabung di BMT NU disamping memenuhi kebutuhan fisiologinya juga ingin menyimpan uangnya dengan rasa aman karena BMT NU dikenal oleh masyarakat yang kepemilikannya dimiliki oleh organisasi NU yang dinaungi oleh kelompok Kyai dan Ulama' NU, sehingga menabung di BMT NU merasa aman dari kehilangan, kecurangan dan bagi hasil yang bersifat riba. Nasabah mengungkapkan apabila disimpan di Lembaga Keuangan non bank lainnnya mereka 
merasa kurangnya keamanan karena banyaknya kasus penggelapan uang, dan juga merasa kurang aman apabila disimpan dirumahnya karena rawannya pencurian dan kehilangan uang disebakan oleh mahluk halus.

3. Kebutuhan akan kasih sayang (love needs)

Menabung di BMT NU memang dimanjakan oleh pelayanan yang ramah dan santun karena semua anggotanya mayoritas alumni pondok pesantren yang berbasis NU, sehingga nasabah merasa nyaman dengan pelayanan yang sopan, setiap hari petugas BMT NU datang kerumah dengan panggilan salam sehingga petugas tersebut mengenal dengan dekat dengan para petugas-petugas yang bertugas dalam produk Tabungan (TABAH) Mudhorobah.

4. Kebutuhan akan harga diri (esteem needs)

Dalam masyarakat pedesaan orang yang menabung dianggap orang yang mampu dan mempunyai harta yang lebih sehingga orang yang menabung di BMT NU diangggap orang yang mempunyai penghasilan lebih dan dianggap mampu bersaing dengan tetangganya, sehingga masyarakat di pedesaan berlomba untuk menabung.

5. Aktualisasi diri (self actualization)

Nasabah termotivasi menabung di BMT NU karena nasabah mampu dan mempunyai penghasilan lebih sehingga nasabah tidak akan menyia-nyiakan layanan yang diterpakan oleh BMT NU sekaligus mengimplementasikan pengetahuannya tentang perbedaan tentang bank Syariah dengan konvensional yang tentunya masyarakat desa sangat takut dengan istilah riba.

\section{Kesimpulan}

Sistem layanan jemput bola merupakan sistem yang sangat bagus dalam memasarkan produk ataupun jasa karena sistem jemput bola merupakan pelayanan yang sangat memanjakan calon ataupun anggota nasabah, banyak produk yang ditawarkan untuk memanjakan nasabah termasuk salah satunya adalah Tabungan (TABAH) Mudhorobah tabungan yang bisa mempermudah anda dalam memenuhi kebutuhan sehari-hari karena setoran dan penarikan dapat dilakukan kapan saja dan memperoleh keuntungan bagi hasil 40\%. Dan menggunakan akad Mudharobah Mutlaqoh. Setoran awal Rp.10.000 selanjutnya minimal Rp. 2500.

Motivasi nasabah menabung di BMT NU tidak lepas dari kebutuhan dan tujuan yang jelas. Yang menurut Abraham H. Maslow bahwa manusia mempunyai lima tingkat atau hierarki kebutuhan, yaitu : Kebutuhan fisiologikal (physiological needs), Nasabah menabung di BMT NU untuk kebutuhan primer dimasa yang akan datang sehingga apabila dibutuhkan dihari-hari berikutnya bisa dengan mudah untuk mengambil untuk memenuhi kebutuhan primernya, kebutuhan rasa aman (safety needs) Alasan Nasabah menabung di BMT NU disamping memenuhi kebutuhan fisiologinya juga ingin menyimpan uangnya dengan rasa aman karena BMT NU dikenal oleh masyarakat yang kepemilikannya dimiliki oleh organisasi NU yang dinaungi oleh kelompok Kyai dan Ulama' NU, sehingga menabung di BMT NU merasa aman dari kehilangan, kecuranagan dan bagi hasil yang bersifat riba, kebutuhan akan kasih sayang (love needs) Menabung di BMT NU memang dimanjakan oleh pelayanan yang ramah dan santun karena semua anggotanya mayoritas alumni pondok pesantren yang berbasis NU, Kebutuhan akan harga diri 
(esteem needs) Dalam masyarakat pedesaan orang yang menabung dianggap orang yang mampu dan mempunyai harta yang lebih sehingga orang yang menabung di BMT NU diangggap orang yang mempunyai penghasilan lebih dan dianggap mampu bersaing dengan tetangganya, sehingga masyarakat di pedesaan berlomba untuk menabung, Aktualisasi diri (self actualization) Nasabah termotivasi menabung di BMT NU karena nasabah mampu dan mempunyai penghasilan lebih sehingga nasabah tidak akan menyia-nyiakan layanan yang diterpakan oleh BMT NU sekaligus mengimplementasikan pengetahuannya tentang perbedaan tentang bank Syariah dengan konvensional yang tentunya masyarakat desa sangat takut dengan istilah riba.

\section{Daftar Pustaka}

Lilis Saadah, Ervina, (Sistem Layanan Jemput Bola Dalam Meningkatkan Motivasi Menabung Nasabah Pada BMT Muda) (Skripsi, UIN Sunan Ampel Surabaya, 2016)

Muhamad, Manajemen Dana Bank Syariah (Jakarta: Rajawali Pers, 2014)

Philip Koter dan Kevin Lane Keller, Manajemen Pemasaran, edisi 13 (Jakarta: Erlangga, 2009)

Ridwan, Ahmad Hasan, Manajemen Baitul Mal Wa at-tamwil, (Bandung: CV Pustaka Setia, 2013)

Sholichin, Mochlis, Psikologi Belajar, (Surabaya: Pena Salsabila, 2013)

Sugiyono, Metode Penelitian Kualitatif, (Bandung: Alfabeta, 2017)

Triandini, Hendri, "pengaruh Layanan Jemput Bola Produk Funding Terhadap DPK dan Jumlah Nasabah" Jurnal Etikonomi Universitas Prof Muhammadiyah Dr. Hamka, Vol. 12 No. 2, Oktober 2013.

Uzer Usman, Moh, Menjadi Guru Profesional, (Bandung: PT Remaja Rosdakarya, 2004)

Wawancara dengan Bpk H. Rofiqi, tanggal 20 April 2019 di rumah Sejati Camplong Sampang.

Wawancara dengan Ust. Zayadi, tanggal 20 April 2019 di rumah Gruggak Camplong Sampang.

Wina Sanjaya, Strategi Pembelajaran Berorentasi Standar Proses Pendidikan, (Jakarta:Kencana ,2011) 